\title{
Prognostic significance of isolated tumor cells in patients with colorectal cancer in recent 10-year studies (Review)
}

\author{
YOSHITO AKAGI, TETSUSHI KINUGASA, YOSUKE ADACHI and KAZUO SHIROUZU \\ Department of Surgery, Kurume University School of Medicine, Kurume, Fukuoka 830-0011, Japan
}

Received November 1, 2012; Accepted April 18, 2013

DOI: $10.3892 / \mathrm{mco} .2013 .116$

\begin{abstract}
Circulating tumor cells (CTCs) that detach from the primary tumor and move into the circulation are detected in patients with metastatic cancer. The discovery of such cancer cells has been used as a predictor of recurrence and prognosis, although a consensus regarding such applications has not been reached. Peritoneal cytology may be used for identifying high risk of recurrence or mortality, whereas the intraoperative presence of tumor cells in drainage veins, bone marrow, or the liver is not always useful for evaluating the prognosis. The reported positive rate for tumor cells in the peripheral blood of patients with colorectal cancer, including metastasis, has varied from 10 to $80 \%$; however, numerous studies have demonstrated significant differences in the recurrence and mortality rates between patients with and without isolated tumor cells (ITCs) in the peripheral blood. However, the clinical significance of CTCs as an absolute prognostic factor has not been elucidated, since the measurement methodologies and/or the number of cases differed between the studies. Future prospective studies including larger patient populations may elucidate the utility of routine detection of ITCs in daily practice.
\end{abstract}

\section{Contents}

1. Introduction

2. Tumor cells in lymph nodes

3. Tumor cells in the peritoneal cavity

4. Tumor cells in the peripheral blood

5. Tumor cells in drainage veins

6. Tumor cells in the bone marrow

7. Isolated tumor cells in stage IV patients

8. Conclusion

Correspondence to: Dr Yoshito Akagi, Department of Surgery, Kurume University School of Medicine, 67 Asahi-machi, Kurume, Fukuoka 830-0011, Japan

E-mail: yoshisg@med.kurume-u.ac.jp

Key words: colorectal cancer, isolated tumor cells, circulating tumor cells, disseminated tumor cells, prognosis

\section{Introduction}

Biomarkers predictive of the prognosis of colorectal cancer have been investigated using various materials and methods. With advances in immunohistochemistry (IHC) and molecular biology, occult tumor cells, including micrometastases in lymph nodes and circulating tumor cells (CTCs) in the peripheral blood, have been detected in patients with gastrointestinal and breast cancers (1-5). By applying highly sensitive and specific diagnostic techniques, several prospective studies suggested that the presence of isolated tumor cells (ITCs) in peripheral areas, drainage veins and the bone marrow is associated with poor outcomes in colorectal cancer patients (6-9). ITCs are single tumor cells or small clusters of cells, $\leq 0.2 \mathrm{~mm}$ in greatest dimension, detectable by routine hematoxylin and eosin staining or IHC. Several reviews and meta-analyses evaluated clinical studies on ITCs in lymph nodes, peripheral blood, bone marrow and liver and suggested the prognostic significance of such cells in colorectal cancer patients (10-15).

To elucidate the findings of previous clinical studies assessing the prognostic value of disseminated tumor cells (DTCs) in patients with colorectal cancer, we investigated English literature over the past 10 years, using computer searches of PubMed with the following key words: "colorectal cancer', 'micrometastasis', 'occult metastasis', 'circulating tumor cell', 'disseminated tumor cell', 'isolated tumor cell', 'lymph node', 'peritoneal cavity', 'peripheral blood', 'drainage vein', 'bone marrow', 'liver', 'prognosis', and 'survival'. After reading all the abstracts and reviewing the available studies, a total of 87 studies were collected and included in this review.

\section{Tumor cells in lymph nodes}

Between January, 2002 and March, 2012, a total of 31 studies assessed the prognostic value of tumor cells in histologically negative lymph nodes of patients with colorectal cancer (Table I) (16-46). The studies investigated a total of 4,080 patients with colorectal $(n=20)$, colon $(n=7)$ and rectal $(n=4)$ cancer, with a median cohort size of 105 patients. The majority of the studies detected tumor cells using a marker of cytokeratin (CK) and IHC techniques.

Positive rates for tumor cells in histologically negative lymph nodes varied considerably among these studies, ranging from 5 to $88 \%$ (median, 30\%). With median followup periods of 24-128 months (median, 60 months), 16 out of 


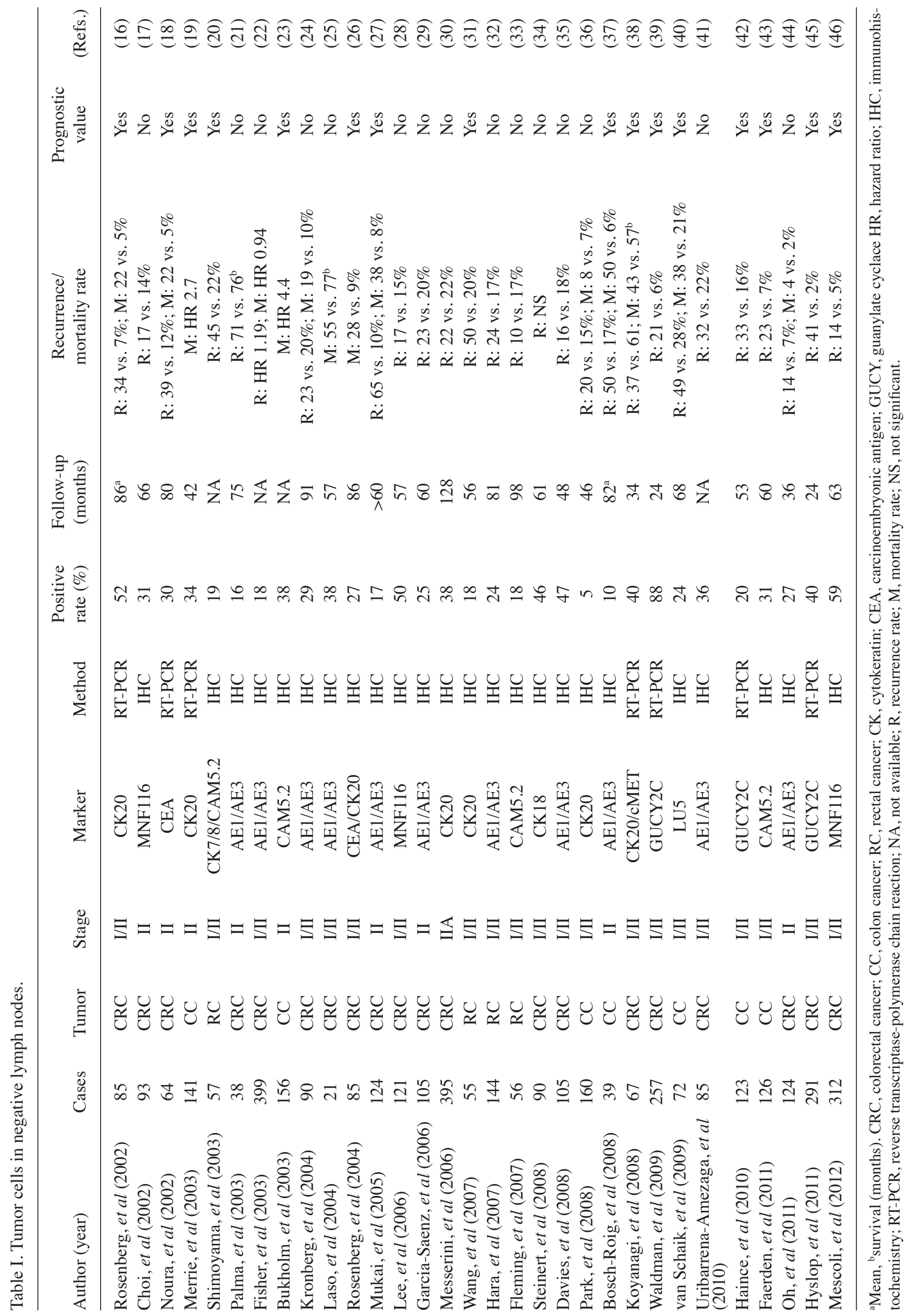


the 31 studies $(52 \%)$ demonstrated a significant difference in recurrence and/or mortality rates between patients with and without ITCs in lymph nodes.

\section{Tumor cells in the peritoneal cavity}

During the same period, 13 studies assessed the prognostic value of tumor cells in the peritoneal cavity of patients with colorectal cancer (Table II) $(34,47-58)$. The studies investigated a total of 2,434 colorectal cancer patients (median, 125 patients). The majority of these studies used standard cytological methods to detect tumor cells in peritoneal lavage samples.

Positive rates for tumor cells in the peritoneal cavity varied among studies, ranging from 2 to 33\% (median, 17\%). The median follow-up period was 47 months (range, 25-103 months) and 9 out of the 13 studies (69\%) demonstrated significant differences in recurrence and/or mortality rates between patients with and without ITCs in the peritoneal cavity.

\section{Tumor cells in the peripheral blood}

A total of 22 studies assessed the prognostic value of tumor cells in the peripheral blood of patients with colorectal cancer (Table III) $(38,59-79)$. The studies included a total of 2,857 patients (median, 103 patients), most of whom had colorectal cancer, with the exception of 2 patients with colon and 1 with rectal cancer only. A total of 13 studies included patients with stage I/II/III disease (Dukes' A/B/C), whereas 9 included patients with stage IV disease (Dukes' D). The majority of the studies detected tumor cells using a carcinoembryonic antigen (CEA) or CK marker and reverse transcriptase-polymerase chain reaction (RT-PCR), IHC, immunomagnetic assay (IMA), or membrane assay (MA) techniques.

Positive rates for tumor cells in the peripheral blood ranged from 10 to $62 \%$ (median, 38\%). Following the exclusion of 9 studies on stage IV patients, the positive rate for tumor cells among the studies was $22-62 \%$ (median, $36 \%$ ). With a median follow-up period of 40 months (range, 24 to $>70$ months), 15 out of the 22 studies (68\%) demonstrated significant differences in recurrence and/or mortality rates between patients with and without ITCs in the peripheral blood. Among the 14 studies including only stage I/II/III patients, $12(86 \%)$ demonstrated a prognostic value of ITCs.

\section{Tumor cells in drainage veins}

Six studies assessed the prognostic value of tumor cells in drainage veins sampled from the mesenteric or portal vein during surgery (Table IV) $(63,65,80-83)$. The studies investigated patients with colorectal cancer, including a total of 638 patients (median, 94 patients). Tumor cells were detected using a CEA marker and RT-PCR.

The positive rate for tumor cells in the drainage vein varied from 11 to $49 \%$ (median, 43\%). With a median follow-up period of 46 months (range, 30 to $\geq 60$ months), 4 out of the 6 studies $(67 \%)$ demonstrated a significant difference in recurrence and/or mortality rates between patients with and without ITCs in the drainage veins.

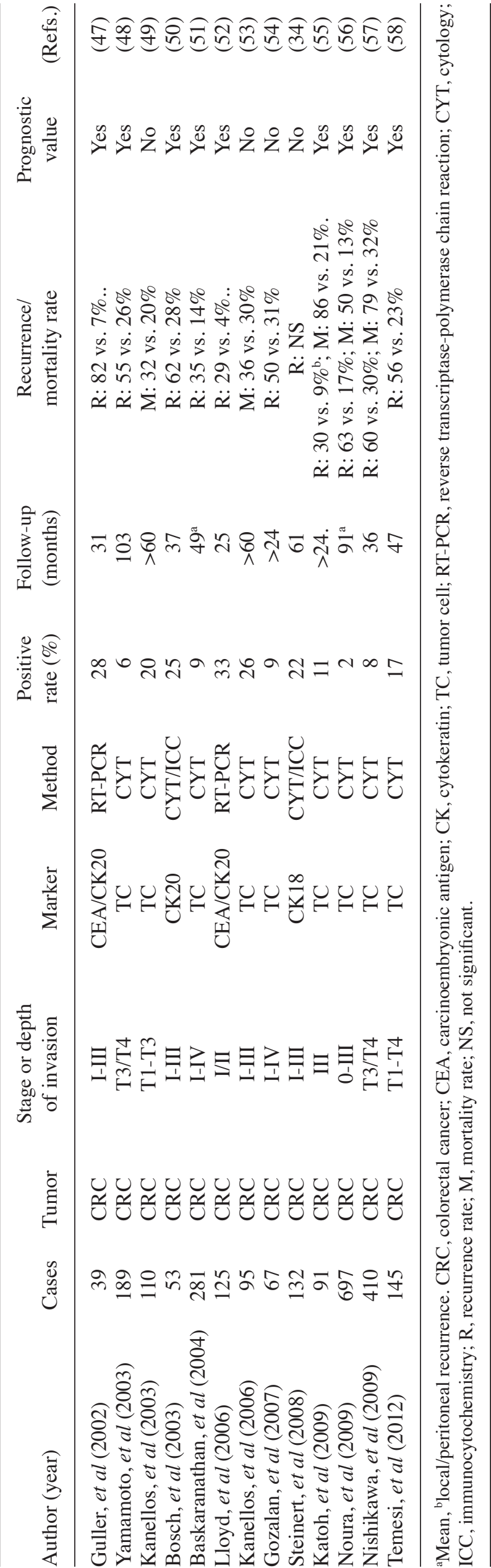




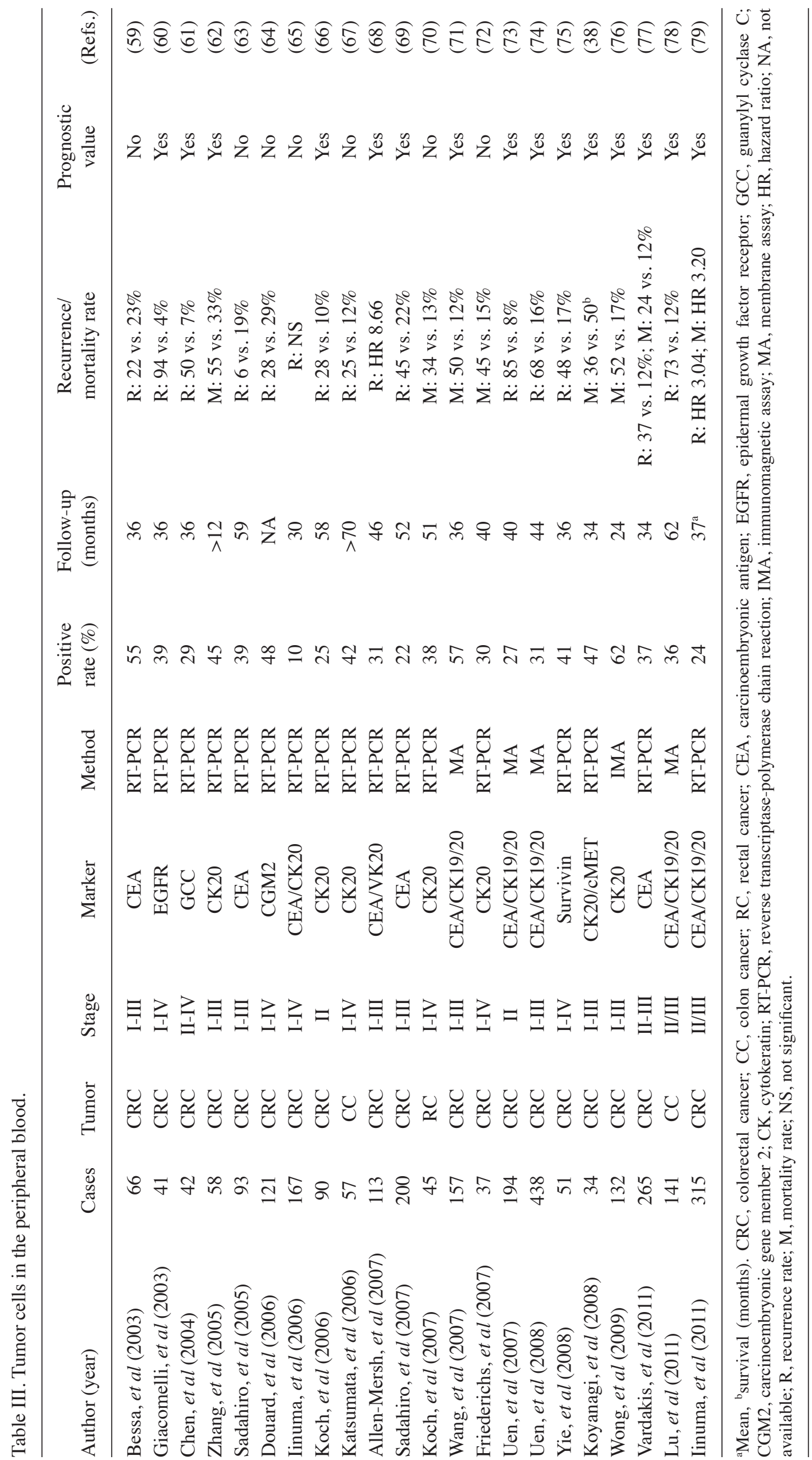



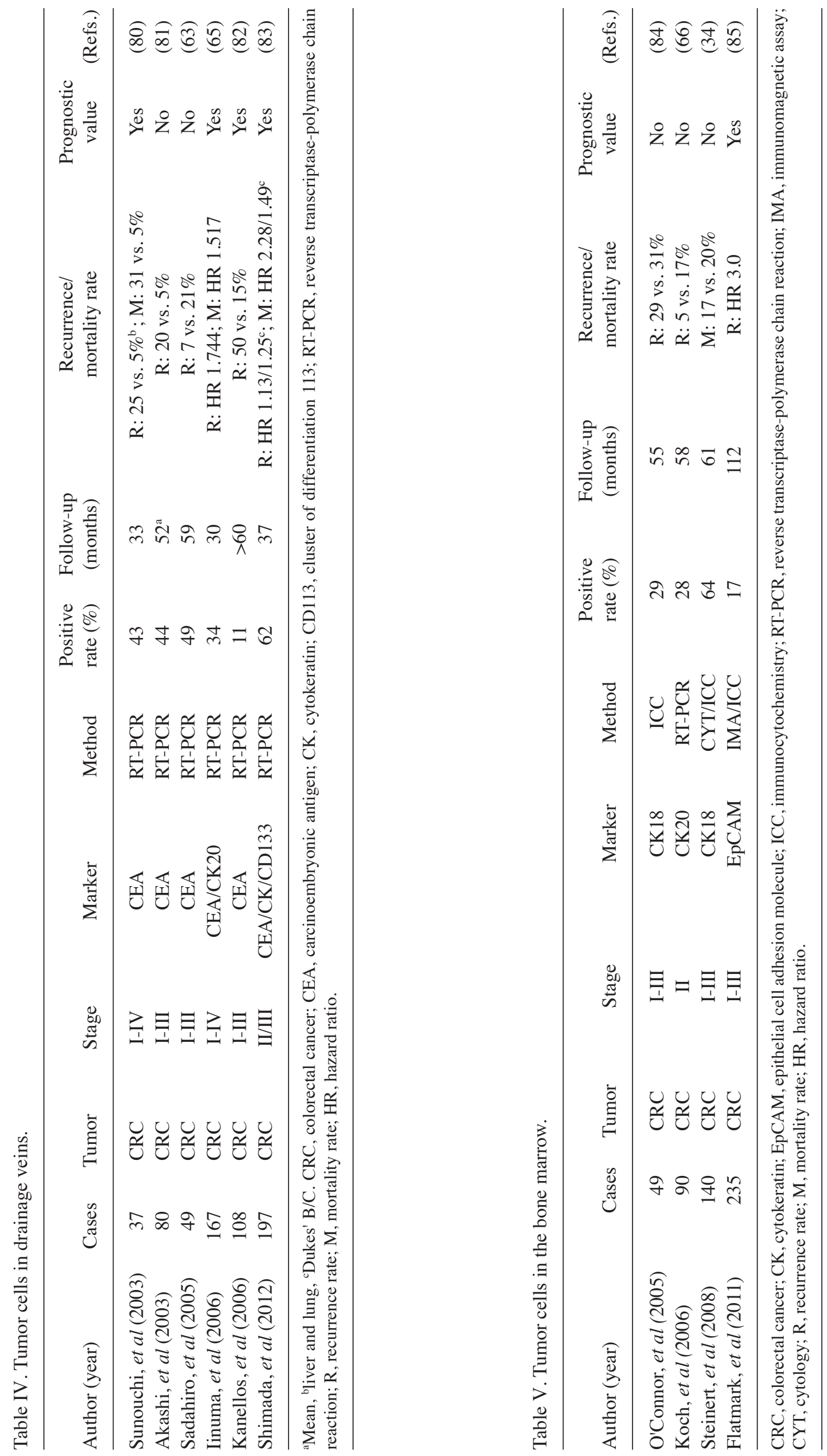


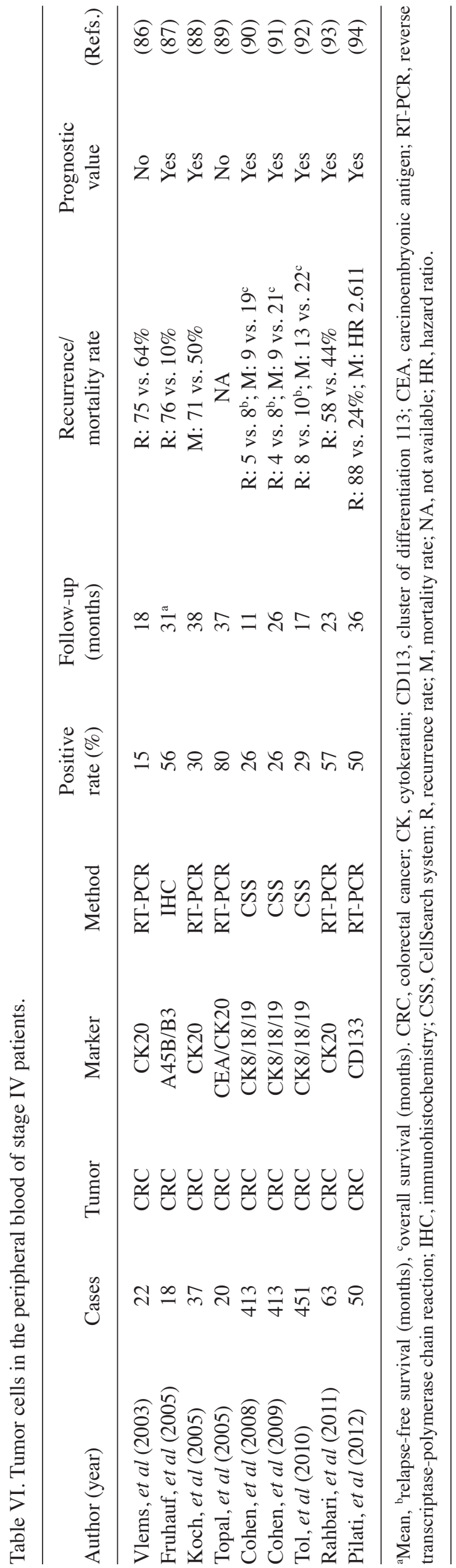

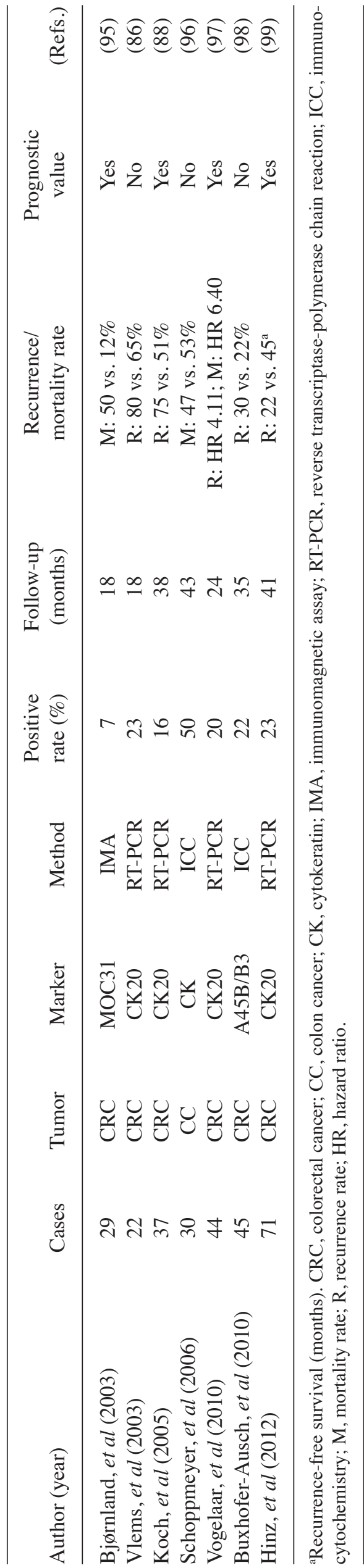




\section{Tumor cells in the bone marrow}

Four studies assessed the prognostic value of tumor cells in the bone marrow (Table V) $(34,66,84,85)$. The studies included a total of 514 colorectal cancer patients (median, 115 patients). These studies detected tumor cells using a CK marker and immunocytochemistry (ICC) or RT-PCR techniques.

Positive rates of tumor cells in the bone marrow varied from 17 to $64 \%$ (median, 29\%). With a median follow-up of 60 months (range, 55-112 months), only 1 in 4 studies (25\%) demonstrated a significant difference in recurrence and/or mortality rates between patients with and without ITCs in the bone marrow.

\section{Isolated tumor cells in stage IV patients}

We identified 9 studies assessing the prognostic value of tumor cells in the peripheral blood of patients with metastatic colorectal cancer (Table VI) (86-94). The positive rate of tumor cells in the peripheral blood varied from 15 to $80 \%$ (median, $30 \%$ ). Median follow-up was 25 months (range, 11 to $\geq 38$ months) and 7 studies (78\%) demonstrated a significant difference in recurrence and/or mortality rates between patients with and without ITCs in the peripheral blood.

Seven studies assessed the prognostic value of tumor cells in the bone marrow of patients with liver metastasis (Table VII) $(86,88,95-99)$. The median positive rate for tumor cells in peripheral blood was $22 \%$ (range, $7-50 \%$ ). The median follow-up period was 35 months (range, 18 to $\geq 43$ months) and 4 studies (57\%) demonstrated a significant difference in recurrence and/or mortality rates between patients with and without ITCs in the bone marrow.

Five studies assessed the prognostic value of tumor cells in the normal liver tissue of patients with liver metastasis, excluding 1 study comprising only stage I/II/III patients (Table VIII) (89,100-103). The positive rate for tumor cells in the peripheral blood varied considerably among the studies (10-70\%; median, 37\%). With a median follow-up period of 44 months (range, 1 to $\geq 5$ months), 3 studies (60\%) demonstrated significant differences in recurrence and/or mortality rates between patients with and without ITCs in the normal liver tissue.

\section{Conclusion}

Although IHC and molecular techniques are useful for detecting tumor cells in histologically negative lymph nodes, the prognostic significance of such cells is equivocal among recent 10-year studies (104). Peritoneal cytology during curative resection ocasionally detects tumor cells and may be useful in identifying a high risk of recurrence or mortality, whereas the presence of tumor cells during surgery in the drainage vein, bone marrow, or liver is not always useful for evaluating the prognosis (105).

Recent studies demonstrated that identifying ITCs in the peripheral blood is useful for estimating the outcome of patients with localized as well as metastatic cancer $(106,107)$. ITCs in the peripheral blood may be measured using the CellSearch system $(4,5,108-112)$ and future prospective studies based on large patient samples and long-term follow-up may elucidate

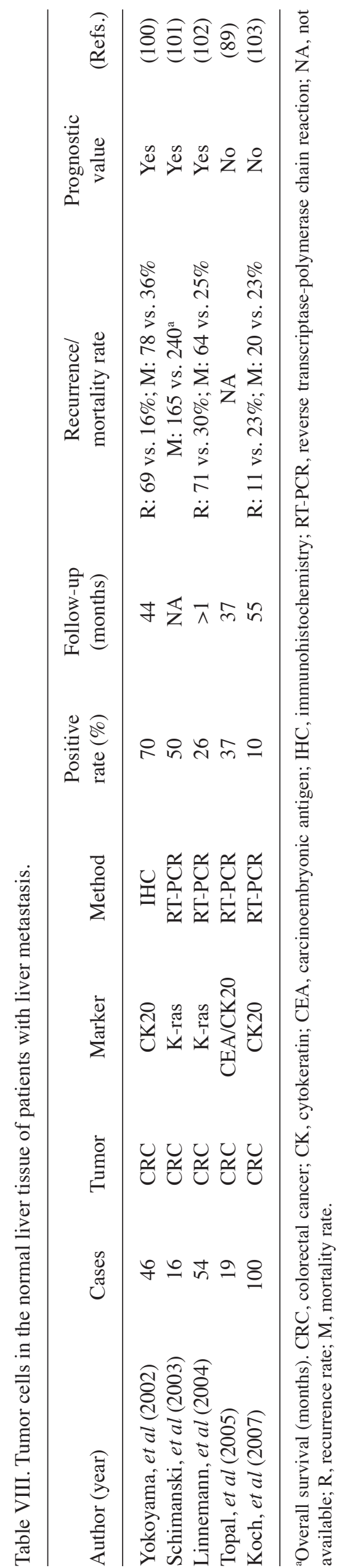


the utility of routine examination for ITCs in the daily practice of colorectal cancer surgery.

\section{References}

1. Hayashi N, Ito I, Yanagisawa A, Kato Y, Nakamori S, Imaoka S, Watanabe H, Ogawa M and Nakamura Y: Genetic diagnosis of lymph-node metastasis in colorectal cancer. Lancet 345: $1257-1259,1995$.

2. O'Sullivan GC, Collins JK, Kelly J, Morgan J, Madden M and Shanahan F: Micrometastases: marker of metastatic potential or evidence of residual disease? Gut 40: 512-515, 1997.

3. Mori M, Mimori K, Ueo H, Tsuji K, Shiraishi T, Barnard GF, Sugimachi K and Akiyoshi T: Clinical significance of molecular detection of carcinoma cells in lymph nodes and peripheral blood by reverse transcription-polymerase chain reaction in patients with gastrointestinal and breast carcinomas. J Clin Oncol 16 128-132, 1998

4. Cristofanilli M, Budd GT, Ellis MJ, Stopeck A, Matera J, Miller MC, Reuben JM, Doyle GV, Allard WJ, Terstappen LW and Hayes DF: Circulating tumor cells, disease progression, and survival in metastatic breast cancer. N Engl J Med 351: 781-791,2004

5. Cristofanilli M, Hayes DF, Budd GT, Ellis MJ, Stopeck A, Reuben JM, Doyle GV, Matera J, Allard WJ, Miller MC, Fritsche HA, Hortobagyi GN and Terstappen LW: Circulating tumor cells: a novel prognostic factor for newly diagnosed metastatic breast cancer. J Clin Oncol 23: 1420-1430, 2005.

6. Funaki NO, Tanaka J, Ohshio G, Onodera H, Maetani S and Imamura M: Cytokeratin $20 \mathrm{mRNA}$ in peripheral venous blood of colorectal carcinoma patients. Br J Cancer 77 1327-1332, 1998.

7. Taniguchi T, Makino M, Suzuki K and Kaibara N: Prognostic significance of reverse transcription-polymerase chain reaction measurement of carcinoembryonic antigen mRNA in tumor drainage blood and peripheral blood of patients with colorectal carcinoma. Cancer 89: 970-976, 2000

8. GuadagniF,KantorJ,Aloe S, Carone MD, Spila A,D'Alessandro R, Abbolito MR, Cosimelli M, Graziano F, Carboni F, Carlini S, Perri P, Sciarretta F, Greiner JW, Kashmiri SV, Steinberg SM, Roselli M and Schlom J: Detection of blood-borne cells in colorectal cancer patients by nested reverse transcription-polymerase chain reaction for carcinoembryonic antigen messenger RNA: longitudinal analyses and demonstration of its potential importance as an adjunct to multiple serum markers. Cancer Res 61: 2523-2532, 2001.

9. Sadahiro S, Suzuki T, Tokunaga N, Yurimoto S, Yasuda S, Tajima T, Makuuchi H, Murayama C and Matsuda K: Detection of tumor cells in the portal and peripheral blood of patients with colorectal carcinoma using competitive reverse transcriptionpolymerase chain reaction. Cancer 92: 1251-1258, 2001.

10. Tsavellas G, Patel H and Allen-Mersh TG: Detection and clinical significance of occult tumour cells in colorectal cancer (Review). Br J Surg 88: 1307-1320, 2001

11. Conzelmann M, Linnemann U and Berger MR: Detection of disseminated tumour cells in the liver of cancer patients. Eur J Surg Oncol 31: 977-985, 2005.

12. Iddings D, Ahmad A, Elashoff D and Bilchik A: The prognostic effect of micrometastases in previously staged lymph node negative (N0) colorectal carcinoma: a meta-analysis. Ann Surg Oncol 13: 1386-1392, 2006.

13. Doekhie FS, Kuppen PJ, Peeters KCMJ, Mesker WE, van Soest RA, Morreau H, van de Velde CJ, Tanke HJ and Tollenaar RA: Prognostic relevance of occult tumor cells in lymph nodes in colorectal cancer. Eur J Surg Oncol 32: 253-258, 2006.

14. Riethdorf S, Wikman H and Pantel K: Biological relevance of disseminated tumor cells in cancer patients (Review). Int J Cancer 123: 1991-2006, 2008.

15. Katsuno H, Zacharakis E, Aziz O, Rao C, Deeba S, Paraskeva P, Ziprin P, Athanasiou T and Darzi A: Does the presence of circulating tumor cells in the venous drainage of curative colorectal cancer resections determine prognosis? A meta-analysis. Ann Surg Oncol 15: 3083-3091, 2008.

16. Rosenberg R, Hoos A, Mueller J, Baier P, Stricker D, Werner M, Nekarda $\mathrm{H}$ and Siewert JR: Prognostic significance of cytokeratin-20 reverse transcription-polymerase chain reaction in lymph nodes of node-negative colorectal cancer patients. J Clin Oncol 20: 1049-1055, 2002.
17. Choi HJ, Choi YY and Hong SH: Incidence and prognostic implications of isolated tumor cells in lymph nodes from patients with Dukes B colorectal carcinoma. Dis Colon Rectum 45: 750-755, 2002.

18. Noura S, Yamamoto $\mathrm{H}$ and Ohnishi T: Comparative detection of lymph node micrometastases of stage II colorectal cancer by reverse transcription-polymerase chain reaction and immunohistochemistry. J Clin Oncol 20: 4232-4241, 2002.

19. Merrie AE, van Rij AM, Dennett ER, Phillips LV, Yun K and McCall JL: Prognostic significance of occult metastases in colon cancer. Dis Colon Rectum 46: 221-231, 2003.

20. Shimoyama M, Yamazaki T, Suda T and Hatakeyama K: Prognostic significance of lateral lymph node micrometastases in lower rectal cancer: an immunohistochemical study with CAM5.2. Dis Colon Rectum 46: 333-339, 2003.

21. Palma RT, Waisberg J, Bromberg SH, Simão AB and Godoy AC: Micrometastasis in regional lymph nodes of extirpated colorectal carcinoma: immunohistochemical study using anti-cytokeratin antibodies AE1/AE3. Colorectal Dis 5: 164-168, 2003.

22. Fisher ER, Colangelo L, Wieand S, Fisher B and Wolmark N: Lack of influence of cytokeratin-positive mini-micrometastases in 'Negative Node' patients with colorectal cancer: findings from the National Surgical Adjuvant Breast and Bowel Projects protocols R-01 and C-01. Dis Colon Rectum 46: 1021-1025, 2003

23. Bukholm IR, Bondi J, Wiik P, Nesland JM, Andersen SN, Bakka A and Bukholm G: Presence of isolated tumour cells in mesenteric lymph nodes predicts poor prognosis in patients with stage II colon cancer. Eur J Surg Oncol 29: 862-866, 2003.

24. Kronberg U, Lopez-Kostner F, Soto G, Zúñiga A, Wistuba I Miranda V, Pinto E, Viviani P and Marshall G: Detection of lymphatic micrometastases in patients with stage I and II colorectal cancer: impact on five-year survival. Dis Colon Rectum 47: 1151-1157, 2004.

25. Laso CA, Gonzalez JJ, Frenso F, Azcano E, Sanz L and Navarrete F: Prognostic value of micrometastases in esophageal and colorectal carcinoma: a clinical experience. Hepatogastroenterology 51: 964-967, 2004

26. Rosenberg R, Friederichs J, Gertler R, Hoos A, Mueller J, Nahrig J, Nekarda H and Siewert JR: Prognostic evaluation and review of immunohistochemically detected disseminated tumor cells in peritumoral lymph nodes of patients with $\mathrm{pN} 0$ colorectal cancer. Int J Colorectal Dis 19: 430-437, 2004.

27. Mukai M, Sato S, Ninomiya H, Wakui K, Komatsu N, Tsuchiya K, Nakasaki $\mathrm{H}$ and Makuuchi H: Recurrence and 5-FU sensitivity of stage II/Dukes' B colorectal cancer with occult neoplastic cells in lymph node sinuses. Oncol Rep 14: 1171-1176, 2005.

28. Lee MR, Hong CW, Yoon SN, Lim SB, Park KJ, Lee MJ, Kim WH and Park JG: Isolated tumor cells in lymph nodes are not a prognostic marker for patients with stage I and stage II colorectal cancer. J Surg Oncol 93: 13-18, 2006.

29. Garcia-Saenz JA, Saenz MC, Gonzalez L, Pérez-Segura P, Puente J, López-Tarruella S, Sastre J, Casado A, López-Asenjo JG and Díaz-Rubio E: Significance of the immunohistochemical detection of lymph node micrometastases in stage II colorectal carcinoma. Clin Transl Oncol 8: 676-680, 2006.

30. Messerini L, Cianchi F, Cortesini $\mathrm{C}$ and Comin CE: Incidence and prognostic significance of occult tumor cells in lymph nodes from patients with stage IIA colorectal carcinoma. Hum Pathol 37: 1259-1267, 2006

31. Wang C, Zhou ZG, Yu YY, Li Y, Lei WZ, Cheng Z and Chen ZX: Patterns of lateral pelvic lymph node metastases and micrometastases for patients with lower rectal cancer. Eur J Surg Oncol 33: 463-467, 2007.

32. Hara M, Hirai T, Nakanishi H, Kanemitsu Y, Komori K, Tatematsu $\mathrm{M}$ and Kato T: Isolated tumor cell in lateral lymph node has no influences on the prognosis of rectal cancer patients. Int J Colorectal Dis 22: 911-917, 2007.

33. Fleming FJ, Hayanga AJ, Glynn F, Thakore H, Kay E and Gillen P: Incidence and prognostic influence of lymph node micrometastases in rectal cancer. Eur J Surg Oncol 33: 998-1002, 2007.

34. Steinert R, Hantschick M, Vieth M, Gastinger I, Kühnel F, Lippert $\mathrm{H}$ and Reymond MA: Influence of subclinical tumor spreading on survival after curative surgery for colorectal cancer. Arch Surg 143: 122-128, 2008.

35. Davies M, Arumugam PJ, Shah VI, Watkins A, Roger Morgan A, Carr ND and Beynon J: The clinical significance of lymph node micrometastasis in stage I and stage II colorectal cancer. Clin Transl Oncol 10: 175-179, 2008. 
36. Park SJ, Lee KY and Kim SY: Clinical significance of lymph node micrometastasis in stage I and stage II colon cancer. Cancer Res Treat 40: 75-80, 2008.

37. Bosch-Roig CE, Rosello-Sastre E, Alonso-Hemandez S, Almenar Cubells D, Grau Cardona E, Camarasa Lillo N, Bautista D and Molins Palau C: Prognostic value of the detection of lymph node micrometastases in colon cancer. Clin Transl Oncol 10: 572-578, 2008

38. Koyanagi K, Bilchik AJ, Saha S, Turner RR, Wiese D, McCarter M, Shen P, Deacon L, Elashoff D and Hoon DS: Prognostic relevance of occult nodal micrometastases and circulating tumor cells in colorectal cancer on a prospective multicenter trial. Clin Cancer Res 14: 7391-7396, 2008.

39. Waldman SA, Hyslop T, Schulz S, Barkun A, Nielsen K, Haaf J, Bonaccorso C, Li Y and Weinberg DS: Association of GUCY2C expression in lymph nodes with time to recurrence and disease-free survival in pN0 colorectal cancer. JAMA 301: 745-752, 2009.

40. van Schaik PM, Hermans E, van der Linden JC, Pruijt JR, Ernst MF and Bosscha K: Micro-metastases in stages I and II colon cancer are a predictor of the development of distant metastases and worse disease-free survival. Eur J Surg Oncol 35: 492-496, 2009

41. Uribarrena-Amezaga R, Ortego J, Fuentes J, Raventós N, Parra P and Uribarrena-Echevarría R: Prognostic value of lymph node micrometastasis in patients with colorectal cancer in Dukes stages A and B (T1-T4, N0, M0). Rev Esp Enferm Dig 102: 176-186, 2010 (In Spanish).

42. Haince JF, Houde M, Beaudry G, L'espérance S, Garon G, Desaulniers M, Hafer LJ, Heald JI, Lyle S, Grossman SR, Têtu B, Sargent DJ and Fradet Y: Comparison of histopathology and RT-qPCR amplification of guanylyl cyclase $\mathrm{C}$ for detection of colon cancer metastases in lymph nodes. J Clin Pathol 63: 530-537, 2010

43. Faerden AE, Sjo OH, Bukholm IR, Andersen SN, Svindland A, Nesbakken A and Bakka A: Lymph node micrometastases and isolated tumor cells influence survival in stage I and II colon cancer. Dis Colon Rectum 54: 200-206, 2011.

44. Oh TY, Moon SM, Shin US, Lee HR and Park SH: Impact of prognosis of lymph node micrometastasis and isolated tumor cells in stage II colorectal cancer. J Korean Sc Coloproctol 27: 71-77, 2011.

45. Hyslop T, Weinberg DS, Schulz S, Barkun A and Waldman SA Occult tumor burden predicts disease recurrence in lymph nodenegative colorectal cancer. Clin Cancer Res 17: 3293-3303, 2011.

46. Mescoli C, Albertoni L, Pucciarelli S, Giacomelli L, Russo VM, Fassan M, Nitti D and Rugge M: Isolated tumor cells in regional lymph nodes as relapse predictors in stage I and II colorectal cancer. J Clin Oncol 30: 965-971, 2012

47. Guller U, Zajac P, Schnider A, Bösch B, Vorburger S, Zuber M, Spagnoli GC, Oertli D, Maurer R, Metzger U, Harder F, Heberer M and Marti WR: Disseminated single tumor cell as detected by real-time quantitative polymerase chain reaction represent a prognostic factor in patients undergoing surgery for colorectal cancer. Ann Surg 236: 768-775, 2002.

48. Yamamoto S, Akasu T, Fujita S and Moriya Y: Long-term prognostic value of conventional peritoneal cytology after curative resection for colorectal carcinoma. Jpn J Clin Oncol 33: 33-37, 2003.

49. Kanellos I, Demetriades H, Zintzaras E, Mandrali A, Mantzoros I and Betsis D: Incidence and prognostic value of positive peritoneal cytology in colorectal cancer. Dis Colon Rectum 46 535-539, 2003.

50. Bosch B, Guller U, Schnider A, Maurer R, Harder F, Metzger U and Marti WR: Perioperative detection of disseminated tumour cells is an independent prognostic factor in patients with colorectal cancer. Br J Surg 90: 882-888, 2003.

51. Baskaranathan S, Philips J, McCredden P and Solomon MJ: Free colorectal cancer cells on the peritoneal surface: correlation with pathologic variables and survival. Dis Colon Rectum 47: 2076-2079, 2004.

52. Lloyd JM, McIver CM, Stephenson SA, Hewett PJ, Rieger N and Hardingham JE: Identification of early-stage colorecta cancer patients at risk of relapse post-resection by immunobead reverse transcription-PCR analysis of peritoneal lavage fluid for malignant cells. Clin Cancer Res 12: 417-423, 2006.

53. Kanellos I, Zacharakis E, Kanellos D, Pramateftakis MG and Betsis D: Prognostic significance of CEA level and positive cytology in peritoneal washings in patients with colorectal cancer. Colorectal Dis 8: 436-440, 2006.
54. Gozalan U, Yasti AC, Yuksek YN, Reis E and Kama NA: Peritoneal cytology in colorectal cancer: incidence and prognostic value. Am J Surg 193: 672-675, 2007.

55. Katoh H, Yamashita K, Sato T, Ozawa H, Nakamura T and Watanabe M: Prognostic significance of peritoneal tumour cells identified at surgery for colorectal cancer. Br J Surg 96: 769-777, 2009.

56. Noura S, Ohue M, Seki Y, Yano M, Ishikawa O and Kameyama M: Long-term prognostic value of conventional peritoneal lavage cytology in patients undergoing curative colorectal cancer resection. Dis Colon Rectum 52: 1312-1220, 2009.

57. Nishikawa T, Watanabe T, Sunami E, Tsuno NH, Kitayama J and Nagawa H: Prognostic value of peritoneal cytology and the combination of peritoneal cytology and peritoneal dissemination in colorectal cancer. Dis Colon Rectum 52: 2016-2021, 2009.

58. Temesi R, Sikorszki L, Bezsilla J, Botos A, Kovács J and Tihanyi T: Impact of intraabdominal lavage cytology on the long-term prognosis of colorectal cancer patients. World J Surg 36: 2714-2721, 2012.

59. Bessa X, Pinol V, Castellvi-Bel S, Piazuelo E, Lacy AM, Elizalde JI, Piqué JM and Castells A: Prognostic value of postoperative detection of blood circulating tumor cells in patients with colorectal cancer operated for cure. Ann Surg 237: 368-375, 2003.

60. Giacomelli L, Gianni W, Belfiore C, Gandini O, Repetto L, Filippini A, Frati L, Aglianò AM and Gazzaniga P: Persistence of epidermal growth factor receptor and interleukin 10 in blood of colorectal cancer patients after surgery identifies patients with high risk of relapse. Clin Cancer Res 9: 2678-2682, 2003.

61. Chen WS, Chung MY, Liu JH, Liu JM and Lin JK: Impact of circulating free tumor cells in the peripheral blood of colorectal cancer patients during laparoscopic surgery. World J Surg 28: 552-557, 2004.

62. Zhang XW, Yang HY, Fan P, Yang L and Chen GY: Detection of micrometastasis in peripheral blood by multi-sampling in patients with colorectal cancer. World J Gastroenterol 11: 436-438, 2005

63. Sadahiro S, Suzuki T, Ishikawa K, Saguchi T, Maeda Y, Yasuda S, Makuuchi H, Yurimoto S and Murayama C: Detection of carcinoembryonic antigen messenger RNA-expressing cells in portal and peripheral blood during surgery does not influence relapse in colorectal cancer. Ann Surg Oncol 12: 988-994, 2005.

64. Douard R, Wind P, Sales JP, Landi B, Berger A, Benichou J, Gayral F, Loric S and Cugnenc PH: Long-term prognostic value of detection of circulating colorectal cancer cells using CGM2 reverse transcription-polymerase chain reaction assay. Surgery 139: 556-562, 2006.

65. Iinuma H, Okinaga K, Egami H, Mimori K, Hayashi N, Nishida K, Adachi M, Mori M and Sasako M: Usefulness and clinical significance of quantitative real-time RT-PCR to detect isolated tumor cells in the peripheral blood and tumor drainage blood of patients with colorectal cancer. Int J Oncol 28: 297-306, 2006.

66. Koch M, Kienle P, Kastrati D, Antolovic D, Schmidt J, Herfarth C, von Knebel Doeberitz M and Weitz J: Prognostic impact of hematogenous tumor cell dissemination in patients with stage II colorectal cancer. Int J Cancer 118: 3072-3077, 2006.

67. Katsumata K, Sumi T, Mori Y, Hisada M, Tsuchida A and Aoki T: Detection and evaluation of epithelial cells in the blood of colon cancer patients using RT-PCR. Int J Clin Oncol 11: 385-389, 2006.

68. Allen-Mersh TG, McCullough TK, Patel H, Wharton RQ, Glover C and Jonas SK: Role of circulating tumour cells in predicting recurrence after excision of primary colorectal carcinoma. Br J Surg 94: 96-105, 2007.

69. Sadahiro S, Suzuki T, Maeda Y, Yurimoto S, Yasuda S, Makuuchi H, Kamijo A and Murayama C: Detection of carcinoembryonic antigen messenger RNA-expressing cells in peripheral blood 7 days after curative surgery is a novel prognostic factor in colorectal cancer. Ann Surg Oncol 14: 1092-1098, 2007.

70. Koch M, Antolovic D, Kienle P, Horstmann J, Herfarth C, von Knebel Doeberitz M and Weitz J: Increased detection rate and potential prognostic impact of disseminated tumor cells in patients undergoing endorectal ultrasound for rectal cancer. Int J Colorectal Dis 22: 359-365, 2007.

71. Wang JY, Lin SR, Wu DC, Lu CY, Yu FJ, Hsieh JS, Cheng TL, Koay LB and Uen YH: Multiple molecular markers as predictors of colorectal cancer in patients with normal perioperative serum carcinoembryonic antigen levels. Clin Cancer Res 13: 2406-2413, 2007. 
72.Friederichs J, Gertler R, Rosenberg R, Dahm M, Nekarda H, Holzmann B and Siewert JR: Correlation of CK20-positive cells in peripheral venous blood with serum CEA levels in patients with colorectal carcinoma. World J Surg 31: 2329-2334, 2007.

73. Uen YH, Lin SR, Wu DC, Su YC, Wu JY, Cheng TL, Chi CW and Wang JY: Prognostic significance of multiple molecular markers for patients with stage II colorectal cancer undergoing curative resection. Ann Surg 246: 1040-1046, 2007.

74. Uen YH, Lu CY, Tsai HL, Yu FJ, Huang MY, Cheng TL, Lin SR and Wang JY: Persistent presence of postoperative circulating tumor cells is a poor prognostic factor for patients with stage I-III colorectal cancer after curative resection. Ann Surg Oncol 15: 2120-2128, 2008.

75. Yie SM, Lou B, Ye SR, Cao M, He X, Li P, Hu K, Rao L, Wu SM, Xiao HB and Gao E: Detection of surviving-expressing circulating cancer cells (CCCs) in peripheral blood of patients with gastric and colorectal cancer reveals high risks of relapse. Ann Surg Oncol 15: 3073-3082, 2008.

76. Wong SC, Chan CM, Ma BB, Hui EP, Ng SS, Lai PB, Cheung MT, Lo ES, Chan AK, Lam MY, Au TC and Chan AT: Clinical significance of cytokeratin 20-positive circulating tumor cells detected by a refined immunomagnetic enrichment assay in colorectal cancer patients. Clin Cancer Res 15: 1005-1012, 2009.

77. Vardakis N, Messaritakis I, Papadaki C, Agoglossakis G, Sfakianaki M, Saridaki Z, Apostolaki S, Koutroubakis I, Perraki M, Hatzidaki D, Mavroudis D, Georgoulias V and Souglakos J: Prognostic significance of the detection of peripheral blood CEACAM5 mRNA-positive cells by real-time polymerase chain reaction in operable colorectal cancer. Clin Cancer Res 17: 165-173, 2011.

78. Lu CY, Uen YH, Tsai HL, Chuang SC, Hou MF, Wu DC, Juo SH, Lin SR and Wang JY: Molecular detection of persistent postoperative circulating tumour cells in stages II and III colon cancer patients via multiple blood sampling: prognostic significance of detection for early relapse. Br J Cancer 104: 1178-1184, 2011.

79. Iinuma H, Watanabe T, Mimori K, Adachi M, Hayashi N, Tamura J, Matsuda K, Fukushima R, Okinaga K, Sasako M and Mori M: Clinical significance of circulating tumor cells, including cancer stem-like cells, in peripheral blood for recurrence and prognosis in patients with Dukes' stage B and C colorectal cancer. J Clin Oncol 29: 1547-1555, 2011.

80. Sunouchi K, Machinami R, Mori M, Namiki K, Hattori S, Murata Y, Tsuchiya T, Mizuno H and Tadokoro M: Clinical impact of carcinoembryonic antigen messenger ribonucleic acid expression in tumor-draining vein blood on postoperative liver metastasis in patients with colorectal carcinoma: a prospective, cohort study. Dis Colon Rectum 46: 467-473, 2003.

81. Akashi A, Komuta K, Haraguchi M, Ueda T, Okudaira S, Furui J and Kanematsu T: Carcinoembryonic antigen mRNA in the mesenteric vein is not a predictor of hepatic metastasis in patients with resectable colorectal cancer: a long-term study. Dis Colon Rectum 46: 1653-1658, 2003.

82. Kanellos I, Zacharakis E, Kanellos D, Pramateftakis MG, Tsahalis T, Altsitsiadis E and Betsis D: Prognostic significance of CEA levels and detection of CEA mRNA in draining venous blood in patients with colorectal cancer. J Surg Oncol 94: 3-8, 2006 .

83. Shimada R, Iinuma H, Akahane T, Horiuchi A and Watanabe T: Prognostic significance of CTCs and CSCs of tumor drainage vein blood in Dukes' stage B and C colorectal cancer patients. Oncol Rep 27: 947-953, 2012.

84. O'Connor OJ, Cahill RA, Kirwan WO and Redmond HP: The impact of bone marrow micrometastases on metastatic disease-free survival in patients with colorectal carcinoma. Colorectal Dis 7: 406-409, 2005.

85. Flatmark K, Borgen E, Nesland JM, Rasmussen H, Johannessen HO, Bukholm I, Rosales R, Hårklau L, Jacobsen HJ, Sandstad B, Boye K and Fodstad Ø: Disseminated tumour cells as a prognostic biomarker in colorectal cancer. Br J Cancer 104: 1434-1439, 2011.

86. Vlems FA, Diepstra JH, Punt CJ, Ligtenberg MJ, Cornelissen IM, van Krieken JH, Wobbes T, van Muijen GN and Ruers TJ Detection of disseminated tumour cells in blood and bone marrow samples of patients undergoing hepatic resection for metastasis of colorectal cancer. Br J Surg 90: 989-995, 2003

87. Fruhauf NR, Kasimir-Bauer S, Gorlinger K, Lang H, Kaudel CP, Kaiser GM, Oldhafer KJ and Broelsch CE: Peri-operative filtration of disseminated cytokeratin positive cells in patients with colorectal liver metastasis. Langenbecks Arch Surg 390: $15-20,2005$
88. Koch M, Kienle P, Hinz U, Antolovic D, Schmidt J, Herfarth C, von Knebel Doeberitz M and Weitz J: Detection of hematogenous tumor cell dissemination predicts tumor relapse in patients undergoing surgical resection of colorectal liver metastases. Ann Surg 241: 199-205, 2005.

89. Topal B, Aerts JL, Roskams T, Fieuws S, Van Pelt J, Vandekerckhove P and Penninckx F: Cancer cell dissemination during curative surgery for colorectal liver metastases. Eur J Surg Oncol 31: 506-511, 2005.

90. Cohen SJ, Punt CJ, Iannotti N, Saidman BH, Sabbath KD, Gabrail NY, Picus J, Morse M, Mitchell E, Miller MC, Doyle GV, Tissing H, Terstappen LW and Meropol NJ: Relationship of circulating tumor cells to tumor response, progression-free survival, and overall survival in patients with metastatic colorectal cancer. J Clin Oncol 26: 3213-3221, 2008.

91. Cohen SJ, Punt CJ, Iannotti N, Saidman BH, Sabbath KD, Gabrail NY, Picus J, Morse MA, Mitchell E, Miller MC, Doyle GV, Tissing H, Terstappen LW and Meropol NJ: Prognostic significance of circulating tumor cells in patients with metastatic colorectal cancer. Ann Oncol 20: 1223-1229, 2009.

92. Tol J, Koopman M, Miller MC, Tibbe A, Cats A, Creemers GJ, Vos AH, Nagtegaal ID, Terstappen LW and Punt CJ: Circulating tumor cells early predict progression-free and overall survival in advanced colorectal cancer patients treated with chemotherapy and targeted agents. Ann Oncol 21: 1006-1012, 2010.

93. Rahbari NN, Reissfelder C, Muhlbayer M, Weidmann K, Kahlert C, Büchler MW, Weitz J and Koch M: Correlation of angiogenic factors with circulating tumor cells and disease recurrence in patients undergoing curative resection for colorectal liver metastases. Ann Surg Oncol 18: 2182-2191, 2011.

94. Pilati P, Mocellin S, Bertazza L, Galdi F, Briarava M, Mammano E, Tessari E, Zavagno G and Nitti D: Prognostic value of putative circulating cancer stem cells in patients undergoing hepatic resection for colorectal liver metastasis. Ann Surg Oncol 19: 402-408, 2012.

95. Bjørnland K, Flatmark K, Mala T, Mathisen O, Bakka A, Aasen AO, Bergan A, Søreide O and Fodstad O: Detection of disseminated tumour cells in bone marrow of patients with isolated liver metastases from colorectal cancer. J Surg Oncol 82: 224-227, 2003

96. Schoppmeyer K, Fruhauf N, Oldhafer K, Seeber S and Kasimir-Bauer S: Tumor cell dissemination in colon cancer does not predict extrahepatic recurrence in patients undergoing surgery for hepatic metastases. Oncol Rep 15: 449-454, 2006.

97. Vogelaar FJ, Mesker WE, Rijken AM, van Pelt GW, van Leeuwen AM, Tanke HJ, Tollenaar RA and Liefers GJ: Clinical impact of different detection methods for disseminated tumor cells in bone marrow of patients undergoing surgical resection of colorectal liver metastases: a prospective follow-up study. BMC Cancer 10: 153, 2010.

98. Buxhofer-Ausch V, Ausch C, Kitzweger E, Mollik M, Reiner-Concin A, Ogris E, Stampfl M, Hamilton G, Schiessel R and Hinterberger W: Spontaneous changes in tumour cell dissemination to bone marrow in colorectal cancer. Colorectal Dis 12: 776-782, 2010.

99. Hinz S, Bockholst J, Roder C, Egberts JH, Schafmayer C, Küchler T, Becker T and Kalthoff H: Disseminated tumor cells in the bone marrow negatively influence survival after resection of colorectal liver metastases. Ann Surg Oncol 19: 2539-2546, 2012.

100. Yokoyama N, Shirai Y, Ajioka Y, Nagakura S, Suda T and Hatakeyama K: Immunohistochemically detected hepatic micrometastases predict a high risk of intrahepatic recurrence after resection of colorectal carcinoma liver metastases. Cancer 94: 1642-1647, 2002.

101. Schimanski CC, Linnemann U, Galle PR, Arbogast R and Berger MR: Hepatic disseminated tumor cells in colorectal cancer UICC stage IV patients: Prognostic implications. Int J Oncol 23: 791-796, 2003.

102. Linnemann U, Schimanski CC, Gebhardt C and Berger MR: Prognostic value of disseminated colorectal tumor cells in the liver: results from follow-up examinations. Int J Colorectal Dis 19: 380-386, 2004

103. Koch M, Kienle P, Logan E, Antolovic D, Galindo L, Schmitz-Winnenthal FH, Schmidt J, Herfarth C and Weitz J: Detection of disseminated tumor cells in liver biopsies of colorectal cancer patients is not associated with a worse prognosis. Ann Surg Oncol 14: 810-817, 2007. 
104. Rahbari NN, Bork U, Motschall E, Thorlund K, Büchler MW, Koch M and Weitz J: Molecular detection of tumor cells in regional lymph nodes is associated with disease recurrence and poor survival in node-negative colorectal cancer: a systematic review and meta-analysis. J Clin Oncol 30: 60-70, 2012.

105. Braun S, Vogl FD, Naume B, Janni W, Osborne MP, Coombes RC, Schlimok G, Diel IJ, Gerber B, Gebauer G, Pierga JY, Marth C, Oruzio D, Wiedswang G, Solomayer EF, Kundt G, Strobl B, Fehm T, Wong GY, Bliss J, Vincent-Salomon A and Pantel K: A pooled analysis of bone marrow micrometastasis in breast cancer. N Engl J Med 353: 793-802, 2005.

106. Rahbari NN, Aigner M, Thorlund K, Mollberg N, Motschall E, Jensen K, Diener MK, Büchler MW, Koch M and Weitz J: Meta-analysis shows that detection of circulating tumor cells indicates poor prognosis in patients with colorectal cancer. Gastroenterology 138: 1714-1726, 2010.

107.Peach G, Kim C, Zacharakis E, Purkayastha S and Ziprin P: Prognostic significance of circulating tumor cells following surgical resection of colorectal cancers: a systematic review. Br J Cancer 102: 1327-1334, 2010.

108. Allard WJ, Matera J, Miller MC, Repollet M, Connelly MC, Rao C, Tibbe AG, Uhr JW and Terstappen LW: Tumor cells circulate in the peripheral blood of all major carcinomas but not in healthy subjects or patients with nonmalignant diseases. Clin Cancer Res 10: 6897-6904, 2004.
109. Budd GT, Cristofanilli M, Ellis MJ, Stopeck A, Borden E, Miller MC, Matera J, Repollet M, Doyle GV, Terstappen LW and Hayes DF: Circulating tumor cells versus imaging - predicting overall survival in metastatic breast cancer. Clin Cancer Res 12: 6403-6409, 2006.

110. Hayes DF, Cristofanilli M, Budd GT, Ellis MJ, Stopeck A, Miller MC, Matera J, Allard WJ, Doyle GV and Terstappen LW: Circulating tumor cells at each follow-up time point during therapy of metastatic breast cancer patients predict progression-free and overall survival. Clin Cancer Res 12: 4218-4224, 2006

111. Riethdorf S, Fritsche H, Muller V, Rau T, Schindlbeck C, Rack B, Janni W, Coith C, Beck K, Jänicke F, Jackson S, Gornet T, Cristofanilli M and Pantel K: Detection of circulating tumor cells in peripheral blood of patients with metastatic breast cancer: a validation study of the CellSearch System. Clin Cancer Res 13: 920-928, 2007.

112. Naoe M, Ogawa Y, Morita J, Omori K, Takeshita K, Shichijyo T, Okumura T, Igarashi A, Yanaihara A, Iwamoto S, Fukagai T, Miyazaki A and Yoshida H: Detection of circulating urothelial cancer cells in the blood using the CellSearch System. Cancer 109: 1439-1445, 2007. 